\title{
College Students' Perceptions on the Issues of Task-based Language Teaching in Mainland China
}

\author{
Yaru Meng \\ School of International Studies, Xi'an Jiaotong University, China \\ Email: yarum@163.com \\ Bing Cheng \\ School of International Studies, Xi'an Jiaotong University, China \\ Email: bch@mail.xjtu.edu.cn
}

\begin{abstract}
The survey was conducted on 96 engineering sophomores in a northwest university in Mainland China with the purpose to investigate their favorite communicative tasks, their perceptions on their task performance as well as their opinions on the teacher role in the classroom. Besides, the study also tries to explore the correlations between different variables like scores of national College English Test Band 4 scores $^{1}$, participation frequency, and self-evaluation of personal performance. The results reveal a panorama of a Chinese task-based English class. First and foremost, the students' preferred tasks are mostly two-way divergent group tasks. In addition, most students reported that participating in the tasks was very "exciting" and "beneficial", while over a quarter students reported that they were somewhat disappointed at their own task performances. Thirdly, they perceived the college English teacher as a facilitator and tutor in learning strategies. Finally, the results show that the more frequent the students participate in different tasks, the better they evaluate their own performance. Besides, the higher the band 4 scores are, the more frequent they are willing to participate. This study sheds lights on the important issues for task-based instruction and helps English teachers and curriculum designers to address the students' needs from the learner's perspectives. Implications for the implementation of task-based language teaching are discussed.
\end{abstract}

Index Terms - Chinese college students, communicative task, task type, participation, teacher role

\section{INTRODUCTION}

One way to push learners to stretch beyond their limited linguistic resources is to engage them in pedagogic communicative tasks. A communicative task is "a piece of classroom work which involves learners in comprehending, manipulating, producing or interacting in that target language while their attention is principally focused on meaning rather than form" (Nunan 1989). The use of different communicative tasks in second language (L2) classroom has been supported by both theoretical and pedagogical arguments (McDonough, 2004). Many studies have examined a variety of aspects of pedagogic tasks. For instance, studies have focused on the impact of task variables on the learners' oral production such as different task types (Slimani-Rolls, 2005), proficiency in the target language (Iwashita 2001; Kim and McDonough, 2008; Leeser,2004; Watanabe and Swain, 2007), task complexity (Robinson, 2001a, 2001b; Skehan and Foster, 1999; YouJin Kim, 2009), task planning time options (Ellis, 2005; Foster and Skehan, 1996) and level of learner participation (McDonough, 2004). These studies lend us different lenses to examine the aspects of TBLL and TBLT. Kim McDonough (2004) explored instructors' and learners' perceptions about the use of pair and small group tasks in a Thai EFL context. The results indicated that the learners believed that peer interaction through pair and small group tasks was useful for practicing oral communication skills. What's more, learners who had more participation during the pair and small group activities demonstrated improved production of the target forms, even though they did not perceive the activities as useful for learning language (McDonough, 2004). But little is know about how they perceive the task types and their own performance as well as their peers'. Ren Rong \& Xu Lanying(2008)explore students and teachers respective perceptions of effective classroom speaking activities in China. The findings indicate that teachers and students sometimes differ on the question of how effective activities are. But their activities are confined to information gap or non-information gap ones, so far little has been done to explore learners' perceptions about the important issues of TBLT in a Chinese EFL context, and even less has anything to do with the correlations between different variables like scores of national College English Test Band 4, participation frequency, and self-evaluation of personal performance.

In terms of research methodology, a large and extensive body of task-based learning (TBL) research based on Long's

\footnotetext{
${ }^{1}$ Band 4 is a national English proficiency test for college students in China. A Band 4 certificate verifies a certain English level of the holder.
} 
Interaction Hypothesis used quantitative and systemic methodology which isolated individual features in task-based interaction for quantitative treatment (Seedhouse \& Almutair, 2009). A problem with systemic approaches is that it allows less detailed analysis of the data and less attention to the perceptions and processes engaged in by the participants (Samuda and Bygate, 2008). Therefore, what is often not the focus of investigation is an in-depth analysis and discussion of the social-interactional components of language learning and use (Firth \& Wagner, 2007). A combination of both quantitative and qualitative approach will help reveal a whole picture of how the students perceive the implementation of tasks in their actual class settings.

\section{THEORETICAL BACKGROUND}

Communicative tasks have been classified differently. Long (1983) categorized tasks into two types: one-way tasks and two-way tasks. One-way tasks are usually static, and information flows in one direction. In these tasks, there is no need to continue the interaction, and the language is predictable. There is often a focus on form. While two-way tasks such as brainstorming, role-plays, simulations, discussions are often dynamic and information flows in more than one direction. Language used here is unpredictable. Although many forms can be used, communication is the most important. In this sense, two-way tasks involve more authentic use of the target language. They are considered more effective than one-way tasks, where one participant has information to give, and the other simply responds to that information (Rani Rubdy,1998).

Compared with individual and class work, group tasks require interdependence. The students in a group must perceive that they "sink or swim" together, that each member is responsible for and dependent on all the others, and that one cannot succeed unless all in the group succeed (Kohn, 1986). Knowing that, peers will rely on each other and highly motivated to fulfill the tasks. Students learn best when they are actively involved in the process. Researchers report that, regardless of the subject matter, students working in small groups tend to learn more of what is taught and retain it longer than when the same content is presented in other instructional formats. Students who work in collaborative groups also appear more satisfied with their classes. (Beckman, 1990; Chickering and Gamson, 1991; Cooper and Associates, 1990; Goodsell et. al. 1992; Whitman, 1988)

Other researchers label the tasks in other terms. They can be divided into convergent tasks and divergent tasks depending on the nature of the goal or outcome that students are required to obtain (Duff, 1986; Pica et al., 1993). Tasks that require learners to pool and exchange information such as role plays, simulations, discussions and problem solving so as to reach a consensus are known as "convergent tasks'. On the contrary, tasks such as debates that require learners to exchange information, but on which no consensus will be reached, are known as "divergent tasks'. There are two controversial findings as to the influences of the two types of tasks on the language production (Andersen \& Richardson,1997; Duff, 1986; Rubdy,1998; Sukchuen,2005), but it is generally believed that divergent tasks have very positive ramifications for the quality of language which is used. There is more chance for learners to stretch their language, both lexically and syntactically and at the level of discourse. There are also longer turns. Divergent tasks will encourage more lengthened sentences and more complex language. Another characteristic is that learners tend to use more clause-chaining and clause-integrating when involved in divergent tasks (Cuesta Cuesta,1997).

\section{RESEARCH SETTINGS AND PROCEDURES}

For a long time in most of the Chinese EFL classrooms, English is taught in structure-based instructional settings, especially for college students who were from the test-oriented EFL teaching context in high school. All the classroom activities are mainly based on textbooks and written exercises. Students spend a lot of time learning about English rather than how to use the language. Even in college, the pressure of National College English Test Band 4 (which stresses less on communicative competency and the pass of it is mandatory in most universities in China) makes the students neglect the interactive skill development. Consequently, it is still hard for them to communicate in English although they learn English for many years. As stated above, task-based language teaching (TBLT) is believed to promote language acquisition by: a) providing learners with opportunities to make the language input they receive more comprehensible; b) furnishing contexts in which learners need to produce output which others can understand; and c) making the classroom closer to real-life language situations. Considering this, the tasks used in TBLT must be carefully chosen to meet those slogans. But how do the participants think of the varied issues related to communicative tasks?

The present study was conducted on 96 second year engineering undergraduate students who had 16 weeks of communicative task-based language teaching. The purposes were to investigate what communicative task types they preferred, and how they evaluated themselves, their peers and how they perceived the teacher's role in the course of task performance.

The research questions are formulated as follows:

1. What are their favorite types of communicative tasks and types of participation?

2. How do they perceive their own performance and their peers' presentations?

3. What do they expect the teacher to do in the communicative task-based language teaching?

4. Are the different variables like frequency of participation, personal perception about the participation frequency, self-evaluation of their own performance and Band 4 scores correlated? 
The subjects were engineering sophomores taught by the same teacher in a northwest university in mainland China, of which 76 (79.2\%) were male students, 20 (20.8\%) female. 88 subjects had Band 4 scores, 85 have passed (60 or above)(see table 1). This will ensure that the majority are not under the pressure of Band 4 . The subjects with Band 4 records were divided into 3 groups based on the Band 4 score. Those who don't have the Band 4 score are not taken into consideration when doing statistics.

TABLE 1

THREE DIVISIONS OF STUDENTS WITH BAND 4 RECORDS

\begin{tabular}{|c|c|c|c|}
\hline & Group 1 & Croup 2 & Group 3 \\
\hline Score range & 65 and below & $66-80$ & 81 and above \\
\hline No. of Students & 14 & 47 & 27 \\
\hline Total & & & 88 \\
\hline
\end{tabular}

When the survey was conducted, the current subjects just finished their spring semester, during which they spent most of the class time in a variety of communicative task-based activities. They are encouraged to participate in each task. Every performance is evaluated and graded by the teacher, and $20 \%$ of their course final score is determined by their oral tasks participations like discussions or debates. Another $20 \%$ is allocated to the written, listening and reading assignments. Therefore the subjects are at least highly extrinsically motivated to participate in communicative tasks if they are not intrinsically motivated.

The grouping criteria for tasks depend on the nature of the tasks. If the tasks don't need much preparation, the students group themselves according to physical proximity in the classroom settings; otherwise, the teacher name the group leaders and let them organize themselves into their own groups. Each group leader is encouraged to include both active and inactive students so that every one in the class is embraced.

The design of a task is seen as potentially determining the kind of language use and opportunities for learning that arises. Tasks in table 2 cover all aspects of language learning (listening, speaking, practical writing and reading), and they range from one-way convergent presentation to two-way divergent talent shows and debates. They are categorized below based on the criteria that whether they were one-way or two-way and whether they were convergent or divergent (see Table 2).

TABLE 2

TASKS CONDUCTED IN THE CLASSROOM

\begin{tabular}{|c|c|c|}
\hline Task Types Conducted & One-way tasks & Two-way tasks \\
\hline Convergent tasks & Listening, reading, practical writings & Role-play,problem solving discussion \\
\hline Divergent tasks & $\begin{array}{c}\text { Mini-speech, practical writings, Speech } \\
\text { contest, movie review, oral, presentations, } \\
\text { book review, talent shows }\end{array}$ & $\begin{array}{c}\text { Job interview, } \\
\text { movie discussions, mock job interview, } \\
\text { debates }\end{array}$ \\
\hline
\end{tabular}

A questionnaire survey consists of 10 multiple choice questions (each with an open choice for the student to add more information if needed) and 2 open questions at the end for overall evaluation and suggestions. The students were assured that the survey was anonymous and had nothing to do with their final scores (This was stated at the top of the page too). The data collected was processed by SPSS 16.0 (Statistics Package for Social Science). The open questions responses are transcribed and analyzed and then tabulated according to the reoccurring themes. They are then analyzed to obtain the most shared themes.

\section{RESULTS AND DisCUSSIONS}

\section{A. What are their Favorite Communicative Tasks and Types of Participation?}

This question item (No.2) is formulated as: please list the numbers of your favorite tasks in the order of your preference from the most preferred to the least ones (for the tasks, see table 2). The statistics show $36.5 \%$ students chose movie appreciation and discussion as their first choices. $14.5 \%$ students chose debates and another $14.5 \%$ chose talent shows. The three constitute $65.5 \%$ of all the responses, and the three types happen to be divergent and two-way tasks (see table 2). In stark contrast, practical writing, in-class listening and book review were the three first choices with the least number of students (2, 3 and 1 responses respectively). They happen to belong to one-way convergent individual tasks.

Their choices can also be further verified by the answers to question item No. 1, (What are your preferred teaching modes after you passed Band 4?). For this question, students were asked to choose the choices and put down them in the order of preference from the most to least preferred ones (See Chart 1). The top two modes of the first preferred choices are D practical English courses like Western Culture, Business English, Newspaper English, and etc(39.6\%). and E relaxed and flexible communicative tasks(20\%). The least preferred one is B (1\%) Move on to the next course book. 


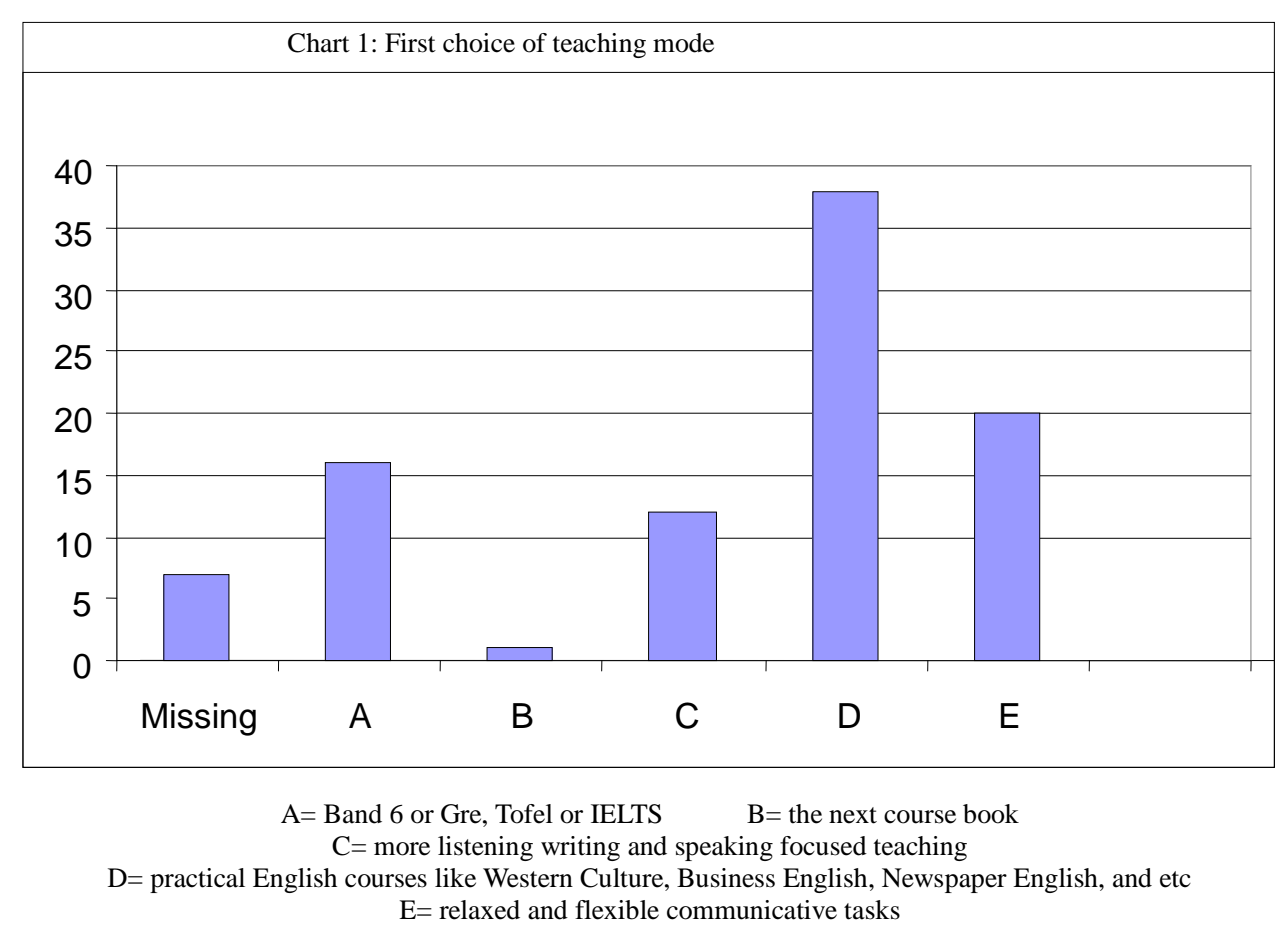

With regard to their favorite types of participation, the question (Item No. 4) is: what types of activities do you prefer, individual work, pair work, team work or class work? $56.3 \%$ students choose team/group work. Next come individual work (18.8\%), pair work $15.6 \%$ and class work (7.3\%). And the results indicate no significant difference in terms of sex and Band 4 score.

It is interesting to find that the target subjects are in favor of tasks involving the collaboration of several students and with more than one acceptable answer or solution - two way divergent tasks. They are linguistically upper intermediate learners and cognitively matured, so it is natural that they prefer to use English in the authentic and meaningful communicative tasks. Of course the frequent participation in these tasks will facilitate linguistic development. In fact, their perceptions coincide with the accepted notion about tasks. Slimani-Rolls(2005)states that"there is a general consensus among researchers... that the use of two - way tasks in group work and pair work provides favorable settings for learners to negotiate meaning. And the use of communicative adjustments generated in the two-way communication task was indeed significantly higher than in the one-way task and the decision-making task." In addition, divergent tasks require significant new knowledge exchanges. They allow participants to perform differently according to their cognitive styles and language competence, which might lead to different outcomes. Questioning in divergent tasks will also encourage students to generate further questions. In this case, two-way divergent group tasks give the participants more chances to communicate in the target language in the less stressful way. They don't have to worry if they have the "only correct answer" as in a convergent task.

\section{B. How do they Perceive their Own and their Peers' Performance?}

1) (Item No.5) After my participation, I ...

As can be seen from the Chart 2 below, of the first two choices from the subjects, the top three repeatedly emerging ones are A $(32.3 \%)$ "I was very excited because I participated", B (29.2\%) "I was disappointed because I didn't perform as I had expected" and C (24\%) "I learned a lot, very beneficial"), with only marginal differences in between. It is good to know altogether $56.3 \%$ subjects feel very positive after they participate in the tasks, but still, the rate of dissatisfaction after performance was surprising. 
Chart 2: After my participation, I...

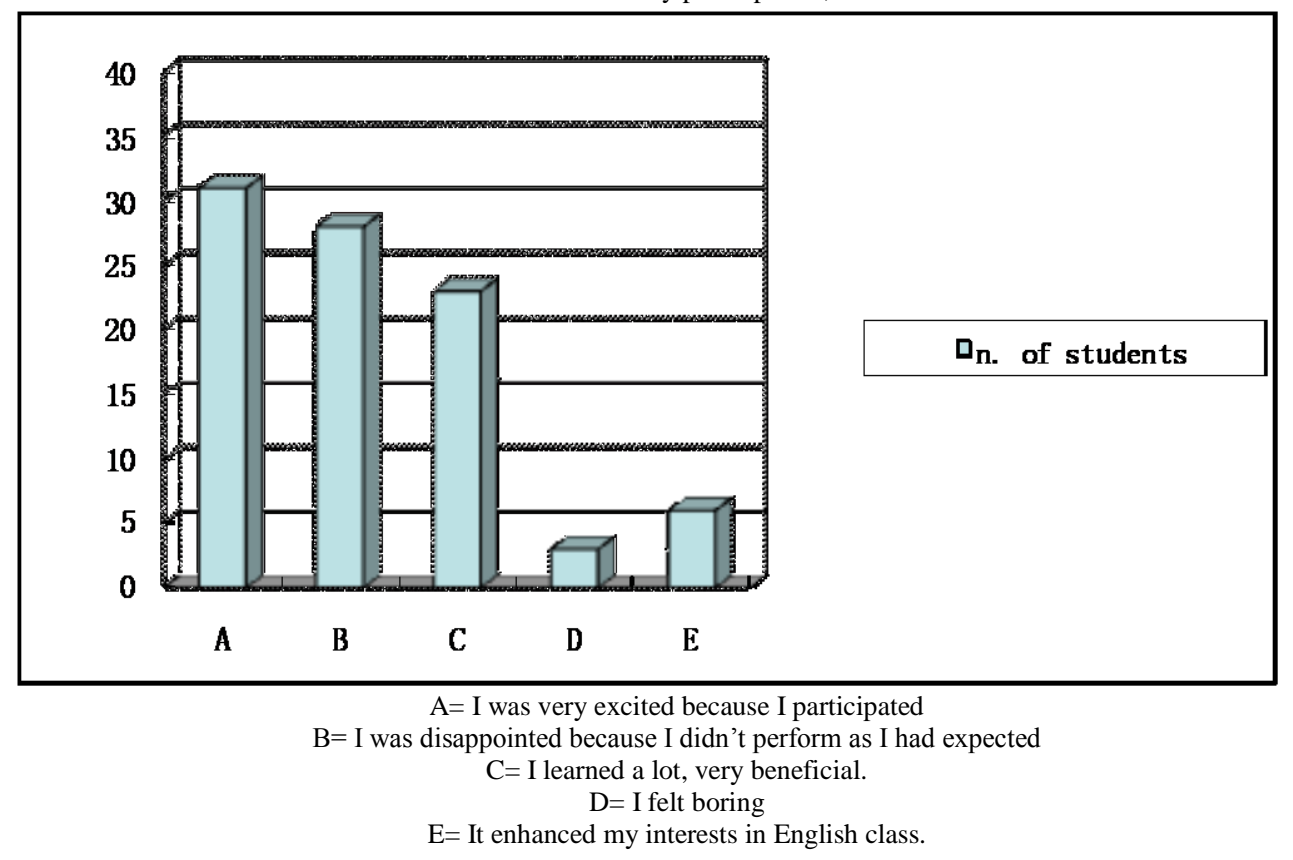

2) (Item No. 6) When my classmates participated in the front, I felt...

For the top choice, 40 students (41.7\%) chose A "I listened attentively because they were mostly very interesting", 21 students $(21.9 \%)$ chose C "I could not catch them even if I wanted (to give them attention), because of their poor pronunciation". The results indicate that, by nature, the students were very supportive when their peers performed their tasks, but the big problem for some students was that they could not understand what their classmates conveyed because of the performers' poor pronunciation, or, sometimes, uninteresting contents, as choice B (13.5\%) indicates (see table 3 below). Coupled with the subjects' own small vocabulary as choice E (12.5) shows, it makes it even harder for both the performers to express themselves clearly and the audience to comprehend fully.

One more thing worth mentioning for this situation is that most students lack the experience of public speaking or class presentation, and when they "went to the front, looking at the whole class, their minds just turn blank" and they "found it really hard to present whatever they have prepared beforehand as planned". So that is why many students think their peers' presentations less than satisfactory.

TABLE 3

WHEN MY CLASSMATES PARTICIPATED IN THE FRONT, I FELT. .

\begin{tabular}{|c|c|c|c|c|c|}
\hline & & Frequency & Percent & Valid Percent & Cumulative Percent \\
\hline \multirow[t]{8}{*}{ Valid } & & 2 & 2.1 & 2.1 & 2.1 \\
\hline & A & 40 & 41.7 & 41.7 & 43.8 \\
\hline & B & 13 & 13.5 & 13.5 & 57.3 \\
\hline & $\mathrm{C}$ & 21 & 21.9 & 21.9 & 79.2 \\
\hline & D & 7 & 7.3 & 7.3 & 86.5 \\
\hline & $\mathrm{E}$ & 12 & 12.5 & 12.5 & 99.0 \\
\hline & $\mathrm{F}$ & 1 & 1.0 & 1.0 & 100.0 \\
\hline & Total & 96 & 100.0 & 100.0 & \\
\hline
\end{tabular}

$\mathrm{A}=\mathrm{I}$ listened attentively because they were mostly very interesting

$\mathrm{B}=\mathrm{I}$ was not interested because there was nothing worth listening

$\mathrm{C}=\mathrm{I}$ could not catch them even if I wanted, because of their poor pronunciation

$\mathrm{D}=\mathrm{I}$ could not catch them even if I wanted, because their voice was too low $\mathrm{E}=\mathrm{I}$ could not catch because my small vocabulary $\mathrm{F}=\mathrm{My}$ idea is

The above mentioned three reasons partly explained why some students were not very satisfied with their peers' as well as their own performance. In addition, Chinese education in general doesn't give focus to the interactive ability, especially public speaking skills, and this also accounts for the rate of dissatisfaction in the present study. 


\section{What do they Expect the Teacher to Do in the Communicative Task-based Language Teaching? How did they Perceive the Teacher's Role?}

Questions Item 7-10 concern the subjects' perceptions on teacher's role. 43 (44.8\%) students believe the English teacher as "the guide in English learning methods and strategies". 27 (28.1\%) students chose "the organizer of the class communicative tasks and activities". Much fewer students $(11.5 \%)$ chose "imparter of knowledge", (7.3\%) "the evaluator of students' participation" and (5.2\%) "the participant of class communicative tasks". It is apparent that most students have a very definite answer about the teacher's role and they wish the English teacher give them some room and control over the class. Apart from these, it is worth noting that 48 (50\%) students would like student-centered, teacher-facilitated class; 41 (42.7\%) expressed that an English class can be either teacher-centered or student-centered depending mainly on the specific needs. This means most students wanted to take initiative but they would love to follow their teachers, like in lecture form, if necessary. This is in opposition to the prevalent belief that student-centered class is more welcomed among the students.

For the question "What do you expect the teacher to do before the participation of the tasks", 67 students (69.7\%) chose "let us know the tasks as early as possible so that we can be well prepared"; 14 (14.6\%) chose "specify clearly the requirements and rules" and 12 (12.5\%) "give examples and models". For the question "What do you wish the teacher to do while you are participating?" 71 students (74.0\%) chose "encourage and assist me". The next choice was "do not interrupt me even my voice is low or whatever". For the question "what you expect the teacher to do after the participation", 64 students $(66.7 \%)$ chose "give me pertinent and sincere feedback and wish".

These figures further confirm that the teacher's role is very critical before, while and after the tasks. Before the tasks, it is very necessary to let the students know what they are expected to do as early and clearly as possible. This will give the students more time to search more materials and internalize them. As Poster\& Skehan (1999) put it "...pre-task planning can have beneficial effects upon the nature of task performance, consistently leading to greater fluency and complexity and, less dependably, greater accuracy". Boston (2008) expresses similar meaning when talking about pre-task and learning. In his words “...learners inevitably 'mine' wordings contained in pre-task and task materials when performing tasks, even when the teacher did not explicitly draw learner attention to these features".

The subjects' responses also show that whatever their performance, they need the teacher's encouragement and timely feedback (post-task). The post-task work could be to check the answers, to answer and clarify questions or just comment on the presentation or illicit listener questions. McDonough and Chaikitmongkol (2007) express the similar idea when they say "...task-based courses should provide teachers with time to respond to their learners' needs as they arise incidentally". Without this opportunity, accuracy in the target language may be reduced.

About open questions, the first one is to ask the students to evaluate the course. Their responses are very positive and encouraging. This validates the relative high rate of positive feeling after they participate. Words like "dynamic atmosphere", "creative activities", "effective method", "interesting and meaningful", "inspiring", "highly motivated and enthusiastic", "variety and flexibility" and "well organized" appear very frequently in the responses. The subjects holding these views account for 79\%. They happen to be frequent participators. 13\% subjects don't think the TBLT any special. They stick to the belief that learning English is to acquire more vocabulary and doing more exercises. Speaking tasks seem fun but don't make them feel they have learned something. A few express feeling bored when some tasks take more time than they think necessary. 8\% students don't answer the question. The latter two groups of respondents happen to be less frequent participators. Some students also express their suggestions for improvement such as more encouragement, specific task requirements, more teacher involvement and appropriate feedback and etc.

The second open question is about their comments on the teacher. Almost all subjects appreciate the teacher's devotion, responsibility and competence very much. $9 \%$ students hold themselves accountable for some inefficiency because they were busy preparing for Band 4 or Band 6 or even TOFELl or GRE. In this case, they lack time and motivations.

\section{Are the Different Variables like Frequency of Participation, Personal Perception about the Participation Times Personal Grading of their Own Performance and Band 4 Scores Correlated?}

Item 3 goes like this: how many times did you participate? What do you think your frequency of participation? How much you will give your performance in a 10-socre scale? The correlation analyses of the above 4 variables (including band 4 scores) indicated that (see Table 4):

As illustrated in Table 4, the frequency of participation and self-evaluation of their performance were correlated (.368) at the 0.01 level. That meant the more they participated, the better they evaluate their performance.

Frequency of participation and Band 4 scores were correlated (.250) at the 0.05 level, indicating that the students who scored higher in Band 4 test were more likely to participate in the class communicative tasks. They were linguistically better prepared or felt more competent when taking part in those activities.

Their personal perception about the participation times and the self-rating of their own performance were significantly correlated (.260) at the 0.05 level. This indicated that the more comfortable they felt about the participation frequency, the better they thought they could do.

The self-rating of their performance was significantly correlated with their Band 4 scores. This reveals that the higher their Band 4 scores were, the better they thought their performances were. 
TABLE 4

2-TAILED T-TEST OF THE CORRELATIONS OF 4 VARIABLES

\begin{tabular}{|c|c|c|c|c|c|}
\hline & & $\mathrm{A}$ & B & $\mathrm{C}$ & D \\
\hline \multirow[t]{3}{*}{$\bar{A}$} & Pearson Correlation & 1.000 & .193 & $.368(* *)$ & $.250(*)$ \\
\hline & Sig. (2-tailed) & . & .082 & .000 & .024 \\
\hline & $\mathrm{N}$ & 90 & 82 & 86 & 82 \\
\hline \multirow[t]{3}{*}{ B } & Pearson Correlation & .193 & 1.000 & $.260(*)$ & -.002 \\
\hline & Sig. (2-tailed) & .082 & . & .019 & .984 \\
\hline & $\mathrm{N}$ & 82 & 84 & 81 & 77 \\
\hline \multirow[t]{3}{*}{$\mathrm{C}$} & Pearson Correlation & $.368(* *)$ & $.260(*)$ & 1.000 & $.232(*)$ \\
\hline & Sig. (2-tailed) & .000 & .019 & . & .037 \\
\hline & $\mathrm{N}$ & 86 & 81 & 89 & 81 \\
\hline \multirow[t]{3}{*}{ D } & Pearson Correlation & $.250(*)$ & -.002 & $.232(*)$ & 1.000 \\
\hline & Sig. (2-tailed) & .024 & .984 & .037 & . \\
\hline & $\mathrm{N}$ & 82 & 77 & 81 & 88 \\
\hline
\end{tabular}

** Correlation is significant at the 0.01 level (2-tailed).

* Correlation is significant at the 0.05 level (2-tailed). A. Frequency of participation,

B. Personal perception about the participation frequency, C. Self-rating of their own performance, D. Band 4 scores.

In the recorded literature, much research can be found to explore how communicative tasks enhance language production, but little is know about the relationship between linguistic competency and participation frequency, the learner's self-rating of their performance. The design of a task is seen as potentially determining the kind of language use and opportunities for learning that arises, and actually it is equally true vice versa. This study reveals that whatever task to employ in class, the most fundamental thing is the essential language needed for carrying out the tasks. Seen from a different perspective, tasks are advised to be designed to cater to the linguistic level of the students so that they can fully participate and can also benefit the most.

\section{CONCLUSION}

This research approaches several issues of communicative task-based language teaching from the student's perspective and also explores the correlations between several variables. The results show that participants preferred two-way divergent group tasks. These tasks prompted significantly more linguistic and conversational adjustments than one-way tasks. Their openness also helps generate more conversation turns, more completions and corrections, more input to an individual learner, and accordingly enhance development of language fluency (Long, 1981). In the future practice, more such tasks should be designed and applied in order for the students to learn more efficiently and enjoyably. This, however, doesn't mean we should rule out the one-way convergent individual or class task.

The fairly high rate of dissatisfaction with self and peer performance in tasks should motivate language teachers and researchers for further research. The language teacher as the facilitator and coordinator should, as the students wish, design the tasks the way most students prefer, and assign the tasks as early as possible. It is even better, according to Candlin (1987), to elicit the tasks from the students themselves because this can guarantee that the tasks best accommodate to their interests and ability. In this case, the preparation period for both the teacher and the students is very crucial to the success of communicative TBLT.

Encouragement and timely feedback from the teacher are also very important factors in motivating students and giving them a sense of achievement. This will help constitute a virtuous cycle considering the present finding that the more frequent they participate, the better they evaluate their performance. When designing tasks, the teacher should also consider the language proficiency levels of the target students because, as the study indicates, the higher scores they have in the proficiency test, Band 4 in this case, the more frequent they like to get involved in different tasks, and the better they feel about themselves. It is advisable that the difficulty levels of tasks administered should vary so that students of every proficiency levels will have a kind of belonging and comfort to be able to function. Or alternatively, the arrangement of the group work should consider the strengths and weaknesses of every student and bring their ability into full play.

As is tested repeatedly that pair and small group tasks provide learners with more time to speak the target language than teacher-fronted activities, promote learner autonomy and self-directed learning, and give instructors opportunities to work with individual learners (Crookes and Chaudron, 2001; Long and Porter, 1985). McDonough \& Chaikitmongkol (2007) further investigated teachers' and learners' reactions to a task-based EFL course at a Thai university using a qualitative analysis. The findings indicate that, both teachers and students believed the task-based EFL course encouraged learners to become more independent and addressed their real world academic needs. However, 
communicative TBLT as a comparatively new teaching approach still needs to be experimented and practiced in further research. It is very imperative that the student needs, proficiency levels and feelings be taken seriously whenever a communicative task is practiced in class. The teacher's role here is also very demanding and critical. Their attention should be appropriately given to every step of a task. For example, it's better to ensure beforehand that students have enough time and language skills to perform the task beforehand. It is suggested that more active participation in tasks can be enhanced by providing learners with pre-task instruction, planning time, and task evaluation. The present research is significant in that it puts the students to the front ground. Further study is needed to probe more about the student needs and their perspectives.

\section{REFERENCES}

[1] Andersen, D. F. \& Richardson, G.P. (1997). Scripts for Group Model Building. System Dynamics Review. 13, 2, $107-129$.

[2] Boston, J. S. (2008). Learner mining of pre-task and task input. ELT Journal 62(1), 66-76.

[3] Candlin, C. (1987). Towards Task-Based Language Learning. In Candlin C., and D. Murphy (eds.), Language Learning Tasks. Lancaster Practical Papers in English Education. Vol. 7. Englewood Cliffs, N.J.: Prentice Hall.

[4] Chickering, A. W, and Gamson, Z. F (eds.). (1991). Applying the Seven Principles for Good Practice in Undergraduate Education. New Directions for Teaching and Learning, No.47. San Francisco: Jossey Bass.

[5] Cooper, J., \& Associates. (1990). Cooperative Learning and College Instruction. Long Beach: Institute for Teaching and Learning, California State University.

[6] Cuesta Cuesta, Ma Rosario. (1997). Task Types. Revista Alicantina de Estudios Ingleses 10: 27-34.

[7] Duff, R. (1986). Another look at interlanguage talk: taking task to task. In R Day (ed.). Talking to Learn: Conversation in Second Language Acquisition. Rowley, Mass : Newbury House.

[8] Firth, A., \& Wagner, J. (2007). Second/foreign language learning as a social interactional accomplishment: Elaborations on a reconceptualized SLA. Modern Language Journal, 91, 798-817.

[9] Ellis. ( 2005). In: R. Ellis, Editor, Planning and Task Performance in a Second Language, John Benjamins, Amsterdam (2005).

[10] Foster and Skehan. (1996). The influence of planning and task type on second language performance, Studies in Second Language Acquisition 18 (1996), pp. 299-323.

[11] Goodsell, A., Maher, M., Tinto, V, and Associates (eds.), (1992). Collaborative Learning: A Sourcebook for Higher Education. University Park: National Center on Postsecondary Teaching, Learning, and Assessment, Pennsylvania State University.

[12] Iwashita et al., (2001). Can we predict task difficulty in an oral proficiency test: exploring the potential of an information processing approach to task design, Language Learning 51 (2001), pp. 401-436.

[13] Kim and McDonough. (2008). The effect of interlocutor proficiency on the collaborative dialogue between Korean as a second language learners, Language Teaching Research 12 (2008), pp. 211-234.

[14] Leeser. (2004). Learner proficiency and focus on form during collaborative dialogue, Language Teaching Research 8 (2004), pp. 55-81.

[15] Long, M. H. (1981). Input, interaction and second language acquisition. In Winitz, H. (ed.), Native language and foreign language acquisition. Annals of the New York Academy of Sciences 379, 259-78.

[16] Long, Mike. (1983). Classroom-oriented research on second language acquisition. Rowley, Mass.: Newbury House.

[17] Long, M. H., \& Porter, P. (1985). Group work, interlanguage talk, and second language acquisition. TESOL Quarterly 19, 2 , 207-27.

[18] Kohn, A. (1986). No Contest: The Case Against Competition. Boston: Houghton Mifflin.

[19] McDonough, K. (2004). Learner-learner interaction during pair and small group activities in a Thai EFL context. System, 32 , 207-224.

[20] McDonough, K. \& Chaikitmongkol, W. (2007). Teachers' and learners' reactions to a task based EFL course in Thailand. TESOL Quarterly 41(1), 107-132.

[21] Nunan, David. (1989). Designing Tasks for the Communicative Classroom. New York: Cambridge University Press.

[22] Pica et al.(1993) Choosing and Using Communicative Tasks for Second Language Instruction. In Crooks et al. Tasks and Language Learning: Integrating Theory and Practice. Clevedon: Multilingual Matters.

[23] Poster, P. \& Skehan, P. (1999). the influence of source of planning and focus of planning on TB performance. Language Teaching Research, 3(3) 1999, p. 215-247

[24] Rubdy, R (1998). Reviews on Kathleen M Bailey And David Nunan (Eds ) Voices From The Language Classroom Qualitative Research In Second Language Education 1996,Applied Linguistics 19/2 272-292

[25] Ren, R. \& Xu, L. (2008).On Designing Group Information Gap Tasks in College English Classrooms-A comparative Study of Students and Teachers Perceptions. Teaching English in China, 2008, (4).

[26] Robinson. (2001). Task complexity, cognitive resources and syllabus design: a triadic framework for examining task influences on SLA. In: P. Robinson, Editor, Cognition and Second Language Instruction, Cambridge University Press, Cambridge, pp. 287-318.

[27] Robinson, P. (2003). The Cognition Hypothesis: Task design, and adult task-based language learning. Second Language Studies 21 (2003), pp. 45-105.

[28] Samuda, V. and M. Bygate. (2008). Tasks in second language learning. Basingstoke: Palgrave Macmillan.

[29] Seedhouse, P.\& Almutairi, S. (2009). A holistic approach to task-based interaction. International Journal of Applied Linguistics Vol: 19, Issue: 3, 311-338

[30] Skehan and Foster, (1999). The influence of task structure and processing conditions on narrative retellings. Language Learning 49, pp. 93-120.

[31] Slimani-Rolls,A. (2005). Rethinking task-based language learning: What can we learn fro m the learners. Language Teaching Research 9/2:175-218. 
[32] Sukchuen, N. (2005). Designing Convergent and Divergent Tasks for an Online English Language Course. Proceedings of the Second International Online Conference on Second and Foreign Language Teaching and Research http://www.readingmatrix.com/onlineconference/proceedings2005.html

[33] Watanabe and Swain. (2007). Effects of proficiency differences and patterns of pair interaction on second language learning: collaborative dialogue between adult ESL learners. Language Teaching Research 11 (2007), pp. 121-142.

[34] Whiteman, N. A. (1988). Peer teaching: to teach is to learn twice. Washington, DC: Association for the Study of Higher Education.

[35] YJ. Kim, (2009). The effects of task complexity on learner-learner interaction. System, Volume 37, Issue 2, 2009, Pages 254-268

Yaru Meng was born in Shaanxi in 1970. She received her M.A. degree in Applied Linguistics in Xi'an Jiaotong University, China, 2003.

She is currently a lecturer in the School of International Studies, Xi'an Jiaotong University, Xi'an, China. Her research interests include language teaching, second language acquisition, language teaching and technology.

Bing Cheng was born in Xi' an in 1972. She received her M.A. degree in Applied Linguistics in Xi'an Jiaotong University, China, 2003.

She is an associate professor in School of International Studies, Xi'an Jiaotong University, Xi'an China. Her research interests include language teaching, language perception and production. 